\title{
Intimate Relations between Women and the German Occupiers in Serbia 1941-1944
}

Relations intimes entre des femmes et des occupants allemands en Serbie, 1941-1944

Ljubinka Škodrić

\section{OpenEdition}

\section{Journals}

Édition électronique

URL : https://journals.openedition.org/ceb/8589

DOI : 10.4000/ceb.8589

ISSN : 2261-4184

Éditeur

INALCO

Édition imprimée

ISBN : 978-2-85831-229-0

ISSN : 0290-7402

\section{Référence électronique}

Ljubinka Škodrić, «Intimate Relations between Women and the German Occupiers in

Serbia 1941-1944 », Cahiers balkaniques [En ligne], 43 | 2015, mis en ligne le 26 juillet 2017, consulté le 06 juillet 2021. URL : http://journals.openedition.org/ceb/8589 ; DOI : https://doi.org/10.4000/ceb. 8589

Ce document a été généré automatiquement le 6 juillet 2021.

\section{(c) (1) \&}

Cahiers balkaniques est mis à disposition selon les termes de la Licence Creative Commons Attribution - Pas d'Utilisation Commerciale 4.0 International. 


\section{Intimate Relations between Women and the German Occupiers in Serbia 1941-1944}

Relations intimes entre des femmes et des occupants allemands en Serbie, 1941-1944

Ljubinka Škodrić

1 After the defeat in the war with Germany in April 1941, the Kingdom of Yugoslavia was divided, and Serbia was occupied by the German military forces. The dissatisfaction of the Serbian population with the new situation lead to an armed uprising, which culminated in autumn of 1941 when the two resistance movements - the communist National Liberation Movement and the royalist Ravna Gora Movement united. Shortly, conflicts broke out between them, which facilitated their defeat. The uprising that was brutally suppressed by the end of 1941 inflicted great losses and suffering on the civilian population, resulting in the pacification of most of Serbia and the adaptation of the people to a life under occupation. ${ }^{1}$

2 With the defeat of masculinity on the home front, sexuality seemed to be the direction in which women's relations with the occupiers would evolve. "Horizontal collaboration" meant having intimate, sexual relations or a love affairs with the members of the occupation forces, that is, an intimate closeness with the enemy that carried specific weight although it had no influence on the outcome of war. This type of collaboration differs from others because it represents an exclusive type of women's collaboration, which although not a violation, represents a threat to national unity. ${ }^{3}$

We can differentiate several types of intimate relations with the occupiers ranging from prostitution, discrete affairs, fraternizing with groups of German soldiers, to relationships that indicated sympathy for the Nazi ideology. The German soldiers basking in the glory of victory and financially well off, had the power of seduction and having intimate relations with them could have been a form of protection and a survival strategy that provided access to food. ${ }^{4}$ For many women such a relationship 
meant achieving short term prominence and social ascent, not only a way to access otherwise inaccessible financial means, but also a form of entertainment and escape from the bleakness of everyday life. However, interest was not always the sole reason for intimate relations with the occupying soldiers, there were emotional ties as well. Some couples fell in love, but their relationships were mostly self-deceiving and regardless of the initial motivation, it was a relationship between two people who were basically not in equal positions.

In conquered Europe, greater tolerance for the behaviour of women existed in countries that had mild occupation regimes and in countries with a large number of German soldiers where the rest of the population also developed close relations with the occupiers. In Norway and Denmark mild occupation regimes and the presence of numerous German troops resulted in a high percentage of women having intimate relations with occupiers. ${ }^{5}$ The fact that a large number of Frenchmen were prisoners of war had its impact on the relations of Frenchwomen with the occupiers. ${ }^{6}$

On territories that had harsh occupation regimes intimate relations with the occupier had special significance because they were linked with the implementation of a racial policy. Intimate relations in the Bohemia-Moravia Protectorate supported the Germanization program. ${ }^{7}$ On the other hand, the German command made futile attempts to prevent sexual contacts of its soldiers with what they perceived the racially inferior Slav population. From the end of 1942, the Nazis started showing special interest in the children fathered by German soldiers on the Eastern Front. Estimates were made that the number of such war children would annually be more than a million. ${ }^{8}$

6 Since WWI the motive of women committing adultery with the occupiers was a very painful subject for Serbian society and it was reflected in literature. Dragiša Vasić a lawyer and writer who was the ideologist of the Ravna Gora movement in WWII had a traumatic personal experience. ${ }^{9}$ Vasić wrote a short story in the interwar period titled "Visiting" describing the postwar depression and alcoholism of a war veteran burdened by the knowledge that his wife had committed adultery during the occupation in WWI. ${ }^{10}$ Other writers too condemned intimate relations with the occupiers, however other aspects of that act were also considered. The scientist Milutin Milanković wrote that civilians in Belgrade perceived with gratitude the activity the mistress of count Salis Sevis, the Austro-Hungarian governor of occupied Serbia, who used her position to help many people. ${ }^{11}$

7 The public expected women to have liaisons with the occupiers at the very beginning of the German occupation of Serbia in WWII. The expectation was supported by the fact that husbands of a large number of women were taken as prisoners of war and sent to POW camps. ${ }^{12}$ The Commissariat of the Ministry of Education banned as early as July 1941 the play "Woman in the Background" due to the vulgarity, ridicule and lack of tact in presenting the immoral behaviour of a women whose husband was in a POW camp. ${ }^{13}$ This topic was a popular and often used one, the "folk poet" Vlaja from Glibovac sang about it entertaining passengers in trains. Apart from condemning it in general, the song singles out the negligence of children as the specific reason for condemnation as was as self-interest that pointed to a kind of prostitution. ${ }^{14}$

8 The first encounter with the occupying soldiers left a positive impression on Serbian women. The German soldiers were mostly young men who behaved politely and decently, especially towards women. ${ }^{15}$ However, this situation changed quickly. Since 
the best German forces were soon sent to the Eastern Front, order in Serbia was kept by small number of German troops, mostly made up of older men who were not disciplined enough, inclined towards drunkenness and who behaved rudely towards the population. ${ }^{16}$

9 Except for the military forces, the civilian population also came into contact with the officials of the German occupation administration. The behaviour of officials was mostly arrogant and haughty and this especially applied to the different security branches of the occupation forces. The police officials were mostly German clerks who were often not qualified enough for their job, but who enjoyed the advantages of the post that kept them away from the front and larger war operations. In their private life most of them were well off, had mistresses and loved to consume alcohol. ${ }^{17}$ The situation was similar in other branches of the occupation forces. The German personnel who operated the railways and was posted in Niš, except for the director of the railway station, all had intimate relations with the local women and some of them even took them to Germany for a visit. ${ }^{18}$

The Serbian public noticed that the German soldiers were "unusually decent, especially in their behaviour towards women". ${ }^{19}$ It was generally considered that the German soldiers behaved more decently and controlled themselves better in regards to women than the numerous Bulgarian soldiers in the occupation troops who were accused of a large numbers of rapes. ${ }^{20}$

11 Since the German military command tried to restrain sexual violence committed by the soldiers, it encouraged their intimacy with prostitutes, but took great care to protect them from venereal diseases. In this respect Serbia on the whole was treated as a risky territory with a large number of people who had sexually transmitted diseases and was thus subjected to strict sanitary control. The Headquarters of the Military Commander of Serbia sent an announcement to all local occupation administrative branches underscoring the ban on sexual relations with Serbian women due to the danger of venereal diseases, and specially warned the German men of women who engaged in prostitution outside the brothels. ${ }^{21}$

12 General poverty and moral failure caused by war had impact on the great increase of prostitution during the occupation. The German occupiers took measures to regulate prostitution in Belgrade as early as May 1941..22 Prostitution was legalized and controlled by law, and the prostitute's health was regularly checked as was the behaviour of women who were suspected of illegal prostitution.

The presence of German soldiers in the cities increased the demand for bars, barrooms, nightclubs, inns, restaurants, taverns and other establishments that had prostitutes. ${ }^{23}$ Prostitutes worked mostly in the inns in the provinces and were often protected by the German soldiers who enjoyed their services. Thus, they had a significant advantage when they came into conflict with the local people. ${ }^{24}$ However, there were cases when the German command protested when certain German soldiers became too intimate with women of easy moral..$^{25}$ Shortly, special brothels were established exclusively for German soldiers in larger centers like Belgrade, Valjevo and Požarevac.

Except for legal prostitution there were different forms of marginal behaviour that included intimate relations with the members of the occupation forces. Such women gained privileged access to supplies or managed to get other forms of benefits that can also be seen as a form of prostitution. Some of them had been prone to immoral 
behaviour before the war and the war with the presence of foreign soldiers facilitated the break down of middle class moral values.

The circumstances of war, especially the absence of men who were either in the military, prisoner of war camps or were killed, caused many women to have extramarital affairs and to lead a more liberal sexual life. ${ }^{26}$ Some of the women who had intimate relations with German soldiers behaved arrogantly and provocatively because they felt superior in regards to their surroundings. ${ }^{27}$ Many of them used their contacts with the soldiers in order to obtain food. ${ }^{28}$

The German soldiers could realize a more direct and intimate contact with women in the cities, thus it was more often the women from the cities who were condemned for immoral behaviour. This was often due to the fact that the German officials and soldiers were accommodated in the houses and flats of the local population. Thus, sharing of accommodation was often the cause for greater intimacy between Serbian women and the German occupiers. Many respectable women from middle class urban families fraternized with the high officials of the occupation forces and even threw parties for them. ${ }^{29}$ The soldiers and their mistresses did not refrain from appearing in public and taking part in the social life - in that respect they were seen as the future social elite. ${ }^{30}$

17 The occupation brought a feeling that previous norms of behaviour have disappeared, so some women became intimate with the occupation soldiers openly in front of their husbands and family. ${ }^{31}$ Sometimes a love affair with the representatives of the occupation forces was had with the tacit consent and approval of the family members even with their encouragement. The husbands often tolerated such behaviour and some even encouraged it because they gained the occupier's protection and could freely engage in smuggling and black market activities. ${ }^{32}$

18 After the war, many denunciations were reported regarded women who threw drunken sprees and organized dances for the German soldiers, as well as denunciations against those women who were seen in the company of only one German soldier with whom they appeared in public. ${ }^{33}$ The occupation forces themselves noted discrete love affairs and the couples were placed under surveillance especially if the partner's political reliability was suspicious. ${ }^{34}$ Some of the girls even eloped with their suitors because of their parent's disapproval. ${ }^{35}$ However, not all relationships were of sexual nature, there were instances of romantic love and plans for divorce were made but they lasted only until the first transfer orders were received which showed how unstable war time love affairs were. Even when a correspondence had been established contacts would soon cease. However, these relationships were not without consequences. Apart from the stigma of the community, many children were fathered by the German soldiers although there is little written data on this issue. It was reported that two women in Požarevac gave birth to illegitimate children as a result of their affairs with German soldiers and one such instance occurred in Smederevska Palanka.

Intimate relations were most easily achieved with the women who were closest to the occupiers, primarily with the ones who worked for the occupation forces as auxiliary personnel. A large number of women worked for the German forces as translators, secretaries, typists, cooks and cleaners. The women who worked for them were often ideologically close to them, and many of them had love affairs with them. It sometimes seemed to be a question of hierarchy, meaning that the women higher up on the ladder had affairs with higher rank officers. ${ }^{36}$ Many of the women who had not been 
ideologically orientated previously, after getting a job started to promote the interests of the occupiers and to spend their free time with them. ${ }^{37}$

The women employees who were recruited as secret agents for the occupier's intelligence service were mostly mistresses of their German employers who counted on their sexual favours in gathering information. Desanka Pajčić Ciga an important intelligence agent was a close associate and mistress of the German intelligence officer Sesil Nassenstein and she continued working in the same capacity with his successor. ${ }^{38}$ The intelligence agent Marion Bruderer used sexual favors to gather intelligence information..$^{39}$ It was suspected that the main job of her secretary was to recruit young and beautiful Serbian girls and women "for the entertainment of German officers". ${ }^{40}$

The most intriguing case among women who collaborated with the German Intelligence Service is the case of Vera Pešić who was the mistress of SS major Karl Kraus in the interwar period and it is believed that she was also the mistress of General Bader, the military commander of Serbia. ${ }^{41}$

The public followed and strongly condemned the intimate relations of women with the occupiers, expecting them to be punished after the war. During the war, women were warned against such behaviour. The initiative came from the members of the Ravna Gora movement. Members of the Ravna Gora Youth movement in the region of Užice reported in January 1943 that they made a list of 33 mostly young women who had intimate relations with the German occupiers. They printed a leaflet with the names of the accused women and secretly distributed it and claimed that it had an effect on the behaviour of certain women named on the list. ${ }^{42}$

The members of the Ravna Gora movement in Kraljevo also used this method and publically posted the names of women who have violated the national honour with their affairs with the occupiers. More than 40 women in Kraljevo had affairs with the members of the German, Bulgarian, Albanian forces as well as with their collaborators. They were accused of giving parties and organizing dances for "the greatest enemies of the Serbian people". ${ }^{43}$

24 The Ravna Gora movement issued several proclamations with the intention of drawing attention to the immoral behaviour of certain women and attempted to change it. The proclamations condemned women "who give their honour to the murders of their brothers", and specially criticized the moral failure of educated women in the cities concluding that such behaviour was a crime committed against the nation as the question was raised how would such immoral women be able to later bring up their children in the national spirit. Their parents were also criticized for moral failure because they had not paid sufficient attention to the upbringing up their children, especially to controlling their daughters. ${ }^{44}$ The conclusion of the proclamations had a threatening character as the other women were advised not to associate with the ones who behaved immorally. ${ }^{45}$

The women who had close relations with the occupiers in France were subjected to attacks since the early days of 1943 . The usual punishment for women accused of collaboration, conducted outside of the courts, was public head shaving. Although less than a half of the women who had their heads shaved were accused of intimate relations with the occupiers, this accusation was considered the women's main offence during the occupation. ${ }^{46}$ 
The shearing became a practice in many European countries in the first half of the 20th century. The first case was reported in Belgium at the end of WWI on account of intimate relations with the members of occupation forces ${ }^{47}$ During the interwar period shearing of women in the Rhine region was racially motivated and directed towards women who opposed the Nazis, who were Jewish or had intimate relations with the Jews. ${ }^{48}$ The women who supported the left political movement in the Spanish civil and latter in the Greek one were also subjected to it. The women in France, Belgium, Denmark, Holland and Norway were subjected to shearing because of their close relations with the occupiers at the end of WWII. ${ }^{49}$

The head-shaving was done exclusively by men, which can be taken as a symbolic act of re-establishing patriotic masculinity by affirming male domination and an act by which men "cleansed the name of nation" which the women polluted by having sexual relations with the enemy..$^{50}$ The shearing was thus an act of purification and the fact that men were the ones who held the scissors had a symbolic sexist meaning. ${ }^{51}$

The compulsory shearing of women as a punishment for collaboration with the occupier or for intimate relations with them was also present in Serbia during the First World War. On the orders of brigade commander Mašan Stojović several women and young girls were sheared because it was known that they either collaborated with or were mistresses of Bulgarian officers or soldiers. ${ }^{52}$

Gora movement punished women by shearing from the very beginning of the occupation 1941 up to 1944 in cases when women had any form of connection with the occupying soldiers. According to Major Velimir Piletić, the commander of the Krajina corps, the heads of two young women were shaved and this act had such a great impact on women that they started to avoid even chance encounters with the occupying soldiers. ${ }^{53}$ On the territory under Piletić's control head shaving and beating was also used in the case of two peasant women who induced abortions that ended in the death. ${ }^{54}$

Most of the shearing in occupied Serbia was done during 1943 and 1944 when the end of the occupation was in sight. Although this act was most used as a punishment for women who had liaisons with the occupation soldiers, there were several cases when other reasons were the cause for such a punishment. Head shaving as a punishment was used in January 1943 in cases of women whose husbands have escaped from the Ravna Gora army ${ }^{55}$ More serious offences committed by women were apart from shearing punished by public beating, but the motives for such a punishment often remained vague and unresolved. It is recorded that, in some cases, shearing and beating of women was conducted because they or their immediate family belonged to the National Liberation Movement..$^{56}$

Sometime the inexplicable motives for shearing pointed to sexual blackmail done by members of the Ravna Gora movement. Several complaints were made that the members of the Ravna Gora movement attacked women and that the ones who rejected their offers for intimate relations were beaten and threatened of being singled out as collaborators of the occupation forces..$^{57}$ There were instances when the suggestions to have the women sheared were given by some Orthodox priests who collaborated with the Ravna Gora movement. ${ }^{58} \mathrm{~A}$ photograph of the shearing was made in Bogovađa. Some members of Ravna Gora movement complained that the head shaving and public beating of women in the Valjevo region in June 1943 were violent and arbitrary ${ }^{59} \mathrm{After}$ the liberation from the German occupation the defeated members of the Ravna Gora 
movement conducted attacks on the families whose members belonged to the National Liberation Movement and shaved the heads of the women who belonged to the National Liberation Movement. ${ }^{60}$

A Swedish journalist published an account of life in Belgrade in April 1944 concluding that "Draža Mihailović's people shave the heads of Serbian women who fraternized with the Germans and Tito's Partisan use even harsher methods". ${ }^{61}$ After the war many women were sentenced to the loss of national honour and forces labour because they had intimate relations with the members of the occupation army. The women who were charged of conducting business with the occupiers were also charged of having intimate relations with them. ${ }^{62}$ In many cases the decisive role at these trails were played by the town gossip. The immorality seen in the act of women having intimate relations with the occupier was treated as an act of national transgression. Women who were known to have been "the mistresses of German officers" have after the war easily become victims of post war repression and have even lost their lives because of their moral transgressions. ${ }^{63}$ On the contrary men who were prisoners of war or who worked as forced labourers in Germany and who had sexual relations with German women were not treated as transgressors of neither national nor moral norms. ${ }^{64}$

Many of the charged women were more often tried in Courts of National Honour than in military courts. The number of charged women was significantly expanded because women who had intimate relation with the collaborators or members of the Ravna Gora movement were also brought to trail. The Court that tried crimes and offences against Serbian national honour in Čačak sentenced 39 people in the whole county, 17 of which were women. Out of this number seven women were sentenced due to qualifications that among other things referred to intimate relations with the members of the occupation army and authority. ${ }^{65}$

Women accused of immoral behaviour during the occupation were often tried in groups after the war. ${ }^{66}$ As an example of a group trial of women charged of intimate and fraternizing relations with the occupiers is the trail held at the Court for the Trail of Crimes and Offences Against Serbian National Honour in Užice. While the Ravna Gora proclamation identified and accused 33 young women from Užice, the communist authorities sentenced nine women mostly from respectable bourgeois families while two of them were acquitted. ${ }^{67}$ All of the convicted women were found guilty on the 25 June 1945 on a group charge "that they had intimate and friendly relations with the members of the occupation army and authorities by often being in the company of German officers and soldiers, German Gestapo police officers as well as in the company of domestic collaborators". For five of the sentenced women that was the only charge. Apart for three women who were sentenced in absentia, the harshest verdict was ten years of loss of national honor and three years of forced labour. However, after her trail was resumed in October 1945 her verdict was reduced to three years loss of national honor and four months of forced labour. The original verdict was contested when the statement made by the main witness was challenged since his motivation was revenge of a rejected man. ${ }^{68}$ That this process had characteristics of a crackdown against political opponents is seen by the fact that among the indicted was Nada Mirković Lautner, wife of the commander of the collaborationist 10th Voluntary Detachment, Miloš Vojinović Lautner and the daughter of Andrija Mirković a merchant and president of the municipality who was shoot in April 1945 by the new authorities. 


\section{BIBLIOGRAPHIE}

\section{Archives}

AJ, (Arhiv Jugoslavije) [Archives of Yugoslavia], 110 (Državna komisija za utvrđivanje zločina okupatora i njihovih pomagača) [State Commission for Investigation of Crimes Committed by the Occupation Forces and their Collaborators] - 55.

AJ, 110, inv. Br. 4252.

AJ, 103-167-183.

AJ, 110-40-107.

AS, (Arhiv Srbije) [Archives of Serbia], G-3, (Ministarstvo prosvete i vera 1941-1944) [Ministry of Education and Religion], f. 62, 35-16-41.

AS, (Arhiv Srbije) [Archives of Serbia], BIA, (Zbirka dokumenata Bezbednosno-informativne agencije) [Collection of Documents from the Security Information Agency], IV-50. 
AS, (Arhiv Srbije) [Archives of Serbia], G-25, (Zemaljska komisija za utvrđivanje zločina okupatora i njihovih pomagača) [Republic Commission for Investigation of Crimes Committed by the Occupation Forces and their Collaborators], f. 9, Zl. Br. 1745.

AS, G-25, Zl. Br. 1772.

AS, BIA, IV-50.

AS, G-25, f. 15, Zl. Br. 2392.

AS, G-25, f. 9, Zl. Br. 1755.

AS, G-25, f. 39, Zl. Br. 5361.

AS, BIA, I-7.

AS, BIA, IV-12.

AS, BIA, I-36.

AS, (Arhiv Srbije) [Archives of Serbia], Đ-2, (Centralni komitet Saveza komunista Srbije) [Central Committee of the League of Communist of Serbia], OK Ar, 59.

IAB, (Istorijski arhiv Beograda) [Historical Archives of Belgrade], UgB-SP (Uprava grada Beograda - Specijalna policija) [Belgrade City Authority - Special Police], III-21/20, k.149/16.

IAB, UgB-SP III-6/17, k.143/15.

VA, (Vojni arhiv) [Military Archives], Na, (Nemačka arhiva) [German Archives], 32-1-3.

VA, (Vojni arhiv) [Military Archives], Ča, (Četnička arhiva) [Četnik Archives], 20-1-35.

VA, Na, 271-1A-3.

VA, Ča. 255-1-52.

VA, Ča. 130-1-12.

VA, Ča. 240-7-26.

VA, Ča. 255-1-54.

VA, Ča, 80-2-45.

Istorijski arhiv Užice, Okružni sud u Užicu [Historical Archives of Užice, District Court of Užice], KNO i konf. Ča/a 1945.

\section{Ouvrages}

ABВOTT Elizabeth, 2006, Istorija ljubavnica [A History of Mistresses], Beograd: Geopoetika. воск Gisela, 2000, Frauen in der Europaischen Geschichte Vom Mittelalter bis zur Gegenwart, München: C.H. Beck Verlag. BOžović Branislav, 1998, Beograd pod komesarskom upravom 1941 [Belgrade Under Commissars' Authority 1941], Beograd.

CVETKOVIĆ Srđan, 2006, Između srpa i čekića: Represija u Srbiji 1944-1953 [Between the Hammer and the Sickle: Repression in Serbia 1944-1953], Beograd.

ĆIRKOVIĆ Simo C., 2009, Ko je ko u Nedićevoj Srbiji 1941-1944. Leksikon ličnosti: Slika jedne zabranjene epohe [Who Is Who in Nedić's Serbia 1941-1944: A Biographical Dictionary, A Picture of A Forgotten Epoch], Beograd. 
DAVIDOVIĆ Goran, TIMOTIJEVIĆ Miloš, s. d., Žena i rat, "Druga strana” okupacije 1941-1944: godine na prostoru čačanskog kraja [Women and War, “The Other Side” of the occupation 1941-1944], Zbornik radova Narodnog muzeja.

DAVIDOVIĆ Goran, TIMOTIJEVIĆ Miloš, 2002, Zatamnjena prošlost: Istorija ravnogoraca čačanskog kraja, I [The Dimmed Past: History of the Ravna Gora Movement in the Čačak area, I], Čačak, 90.

DAVIDOVIĆ Goran, TIMOTIJEVIĆ Miloš, 2004, Dan posle - uništavanje organizacije JVuO i uspostavljanje vlasti komunista u čačanskom kraju 1944-1945 [The Day After - Destruction of the JVuO Organization and Establishment of Communist Rule in the Čačak Area at the End of 1944-1945], Istorija 20. veka, 2/2004, 34 .

FROMMER Benjamin, 2006, "Denouncers and Fraternizers: Gender, Collaboration, and Retribution in Bohemia and Moravia during World War II and After", in WINGFIELD Nancy M., BUCUR Maria, Gender and War in Twentieth-Century Eastern Europe, Bloomington: Indiana University Press. GILDEA Robert, WIEVIORKA Olivier, WARRING Anett, 2006, Surviving Hitler and Mussolini: Daily Life in Occupied Europe, Oxford, New York: Berg.

GLIŠIć Venceslav, 2009, Dosije o Veri Pešić ili kako ne treba pisati istoriju obaveštajca [A File on Vera Pešić or How the History of an Intelligence Agent Should not be Written], Beograd: Vojnoistorijski glasnik, 2/2009.

HANSEN Lulu Anne, 2009, "Youth of the Rails: Teenage Girls and German Soldiers-A Case Study in Occupied Denmark, 1940-1945”, in HERZOG Dagmar, Brutality and Desire, War and Sexuality in Europe's Twentieth Century, New York: Palgrave Macmillan.

MILANKović Milutin, 2005, Sećanja [Memoirs], Beograd.

MILIĆEVIĆ Nataša, 2009, Jugoslovenska vlast i srpsko građanstvo 1944-1950 [The Yugoslav Authority and the Serbian Bourgeoisie 1944-1950], Beograd.

MITROVIĆ Momčilo, 2007, Srpska nacionalna čast pred zakonom 1945: godine [Serbian National Honor Before the Law], Beograd.

MLADENOVIĆ Božica, 1996, Žena u Topličkom ustanku 1917 [A Woman in the Toplica Uprising 1917], Beograd.

MÜHLHÄUSER Regina, 2009, “Between 'Racial Awareness' and Fantasies of Potency in the Occupied Territories of the Soviet Union, 1942-1945", in HERzOG Dagmar, Brutality and Desire, War and Sexuality in Europe's Twentieth Century, New York: Palgrave Macmillan.

NIKOLIĆ Kosta, 1999, Istorija ravnogorskog pokreta 1941-1945 [History of the Ravna Gora Movement 1941-1945], I, Beograd: Srpska reč, 310.

PILETIĆ Velimir, 2002, Sudbina srpskog oficira [The Fate of a Serbian Officer], Kragujevac.

RISTić Nenad J., 1995, Džumbusana u Centralu - Pozorišni Život u Planci Smed 1941-1944 [Chaos in the Central - Theatre Life in Palanaka (Smed) 1941-1944], Smederevska Palanka.

ŠMALE Volfgang, 2011, Istorija muškosti u Evropi (1450-2000) [Wolfgang SCHMALE, History of Masculinity in Europe (1450-2000)], Beograd.

TIMOTIJEVIĆ Miloš, 2007, Prostitucija u Čačku tokom 20. veka [Prostitution in Čačak during 20th century], Tokovi istorije, 1-2/2007.

Utuljena Baština, Antologija (cenzurisanih) pripovedaka [The Surpressed Heritage, Anthology of (Censored) Stories], 1990, Priredio Gojko Tešić, Beograd. 
VINEN Richard, 2007, The Unfree French: Life under the Occupation, London: Penguin books.

VIRGILI Fabrice, 2002, Shorn Women: Gender and Punishment in Liberation France, Berg, Oxford, New York: Berg.

vuKoSAVlJeVić Miladin, 2008, Miroslav Krleža i Dragiša Vasić (Skica za studiju) [Miroslav Krleža and Dragiša Vasić (A Sketch for a Portrait)], Život i delo Dragiše Vasića [The Life and Work of Dragiša Vasić], Zbornik radova sa naučnog skupa, Gornji Milanovac.

\section{NOTES}

1. According to German reports 20,000 mostly civilians were killed in reprisals in the period September 1941 - February 1942. Holm ZUNDHAUZEN, 2008, Istorija Srbije od 19. do 21. veka [Holm SUNDHAusSEN, The History of Serbia 19 and 20 century], Beograd, p. 358.

2. French historiography also uses a softer term "sentimental collaboration" ("collaboration sentimentale"). Richard VINEN, 2007, The Unfree French: Life under the Occupation, p. 176.

3. "Horizontal collaboration" became one of the most unbearable types of collaboration, not on account of its immediate effect, which was negligible, but because it represented the absolute defeat of France." Fabrice VIRGILI, 2002, Shorn Women: Gender and Punishment in Liberation France, p. 239.

4. For many women in Greece intimate relations with the members of the occupation army was the only way to survive a severe famine. Elizabeth ABBOTT, 2006, Istorija ljubavnica, p. 350.

5. About 9000 children were fathered by German soldiers in Norway, and almost 50000 Norwegian women had affairs with German soldiers which was a significant percentage out of a population of 3 million inhabitants. Robert GILDEA, Olivier WIEVIORKA, Anett WARRING, 2006, Surviving Hitler and Mussolini: Daily Life in Occupied Europe, p. 91.

6. Historians estimated that about 50-75 000 children were fathered by German soldiers in France. However, more recent research increased the number to 200000 . VINEN, p. 160.

7. Benjamin FROMMER, 2006, "Denouncers and Fraternizers: Gender, Collaboration, and Retribution in Bohemia and Moravia during World War II and After", p. 121.

8. Regina MÜHLHÄUSER, 2009, "Between 'Racial Awareness' and Fantasies of Potency in the Occupied Territories of the Soviet Union 1942-1945", p. 211.

9. After returning home from the WWI, Vasić's wife told him that she had fallen in love with an Austro-Hungarian officer and that she wanted a divorce. Miladin vuKosAvLJEvić, 2008, Miroslav Krleža i Dragiša Vasić (Skica za studiju), p. 352.

10. "Think about it, who can trust a wife to be loyal during the occupation? Say it. An officer in every house, isn't there? Brother, they live in one house. The elders go to bed, the children fall asleep, there aren't any children in some houses. The only witness is god himself. And when you come back home she (the wife) can't stop talking about honor." Utuljena Baština, Antologija (cenzurisanih) pripovedaka, 1990, p. 42.

11. Her activity was summed up as: "She was a sinner but she did good!" Milutin MILANKović, 2005, Sećanja [Memoirs], p. 379. 
12. Circa 100000 soldiers and officers were taken as prisoners of war from the territory of Serbia.

13. AS, (Arhiv Srbije) [Archives of Serbia], G-3, (Ministarstvo prosvete i vera 1941-1944) [Ministry of Education and Religion], f. 62, 35-16-41.

14. Nenad J. RiSTIĆ, 1995, Džumbusana u Centralu-Pozorišni Život u Planci Smed 1941-1944, p. 33.

15. Goran DAvidović, Miloš TIMoTIJEVIć, s. d., Žena i rat, "Druga strana" okupacije 1941-1944: godine na prostoru čačanskog krajapp, 147.

16. DAVIDOVIĆ, TIMOTIJEVIĆ, 2002, Zatamnjena prošlost: Istorija ravnogoraca čačanskog kraja, I, p. 90.

17. VA, (Vojni arhiv) [Military Archives], Na, (Nemačka arhiva) [German Archives], 32-1-3.

18. AS, (Arhiv Srbije) [Archives of Serbia], BIA, (Zbirka dokumenata Bezbednosnoinformativne agencije) [Collection of Documents from the Security Information Agency], IV-50.

19. VA, (Vojni arhiv) [Military Archives], Ča, (Četnička arhiva) [Četnik Archives], 20-1-35.

20. According to incomplete data of the State Commission for Investigation of Crimes Committed by the Occupation Forces and their Collaborators, 3639 case of rape committed during the occupation were reported, 772 of which were committed by the Germans and 1,834 by the Bulgarians. AJ, (Arhiv Jugoslavije) [Archives of Yugoslavia], 110 (Državna komisija za utvrđivanje zločina okupatora i njihovih pomagača) [State Commission for Investigation of Crimes Committed by the Occupation Forces and their Collaborators] -55 .

21. VA, Na, 271-1A-3.

22. Branislav Božović, 1998, Beograd pod komesarskom upravom 1941, p. 124-125.

23. Miloš тімотіjević, 2007, Prostitucija u Čačku tokom 20: veka, p. 183.

24. Katica Knežević was run out Valjevo by the city police for spreading sexual promiscuity among the soldiers and civilians, she had been arrested before but the German soldiers managed to keep her in Valjevo. IAB, (Istorijski arhiv Beograda) [Historical Archives of Belgrade], UgB-SP (Uprava grada Beograda - Specijalna policija) [Belgrade City Authority-Special Police], III-21/20, k.149/16.

25. The same thing happened to a prostitute who worked at an inn in Lapovo, being by descent from NDH territory, she was returned to her territory of origin. IAB, UgB-SP III-21/23, k.149/20.

26. DAVIDOVIĆ, тімOTIJEVIĆ, 2002, Zatamnjena prošlost..., p. 242.

27. A women from Belgrade shocked the neighbors by seeing off the German soldiers and "appearing outside of her flat in a transparent nightgown." AS, (Arhiv Srbije) [Archives of Serbia], G-25, (Zemaljska komisija za utvrđivanje zločina okupatora i njihovih pomagača) [Republic Commission for Investigation of Crimes Committed by the Occupation Forces and their Collaborators], f. 9, Zl. Br. 1745.

28. AS, G-25, Zl. Br. 1772. 
29. AJ, 110, inv. Br. 4252. There are witness reports that the SS and Police Commander of Belgrade August Meisner had two mistresses who were sisters who came from a respectable Belgrade family - they were shot after the war.

Mi smo preživeli ... Jevreji o holokaustu,II, 2003 [We Have Survived ... Jews on the Holocaust, II], Beograd, p. 324.

30. Milan Jovanović Stoimirović, Head of the State Archives, left a diary entry on the visit to a theatre performance attended by the German and Italian officers who could probably not understand the play but who together with their escorts represented an attraction for the other people present who thought it "was fantastic to see that crowd entering the theatre-the new future world." sToImiRović, date, Dnevnik, rukopis, [Diary, manuscript], Matica srpska.

31. DAVIDOVIĆ, TIMOTIJEVIĆ, 2002, Zatamnjena prošlost..., p. 240-241.

32. AS, BIA, IV-50.

33. AS, G-25, f.15, Zl. Br. 2392.

34. IAB, UgB-SP III-6/17, k.143/15.

35. Parents of a 17 year old school girl from Požarevac asked the District Command in June 1943 to find and return home their daughter who eloped with a German and ran away to Belgrade. AC, BIA, 1-7.

36. Milena Spasić, first a translator in the Field Command in Užice and Šabac and then translator for the Gestapo had a love affair with Paul William, the Head of the Gestapo in Šabac "she completely surrendered to him spiritually and physically and even traveled with him to Germany." AS, G-25, f. 9, Zl. Br. 1755.

37. Two women in Topola, cooks for the German forces, not politically active before the war, became active propagandists of Nazi invisibility after working for the Germans and openly appeared in public and lived with German soldiers. AS, BIA, I-7.

38. Nemačka obaveštajna služba, IV [German Intelligence Service, IV], Beograd, 1959, 211.

39. M. Bruderer was described as a "sexually very aggressive" person who had intimate relations with several mostly young agents. Nemačka obaveštajna služba [German Intelligence Service], p. 289.

40. Simo C. ĆIRKović, 2009, Ko je ko u Nedićevoj Srbiji 1941-1944: Leksikon ličnosti. Slika jedne zabranjene epohe, p. 47.

41. Venceslav GLIšŕc, 2009, Dosi je o Veri Pešić ili kako ne treba pisati istoriju obaveštajca, p. 178.

42. VA, Ča. 130-1-12.

43. VA, Ča. 255-1-52.

44. VA, Ča. 240-7-26.

45. VA, Ča. 255-1-54.

46. From June 1943 to March 1946 in France, 20000 women accused of collaboration with German occupation forces were shorn, $40 \%$ of the charges were for prostitution or sexual relations with the enemy. Volfgang šMALE, 2011, Istorija muškosti u Evropi (1450-200), p. 251.

47. VIRGILI, p. 213. 
48. [...] "Aryan women who had or supposedly had affairs with Jews were sheared and dragged through the city streets." Gizela вок, 2005, Žena u istoriji Evrope: Od srednjeg veka do danas, Beograd, 336, trad. Ljubinka Milenković.

49. The first case of head shaving took place in Denmark 1940, from 1943 on the number of case increased. Lulu Anne HANSEN, 2009, “'Youth of the Rails': Teenage Girls and German Soldiers-A Case Study in Occupied Denmark 1940-1945”, p. 139.

There were cases of women being shorn in Italy because of collaboration with the German occupiers after the capitulation. VIRGILI, p. 214.

50. ŠMALE, p. 252.

51. GILDEA, WIEVORKA, WARRING, 2006, Surviving Hitler and Mussolini..., p. 121.

52. The wife of Mašan Stojović was punished more severely, she was shot because of her collaboration with the Bulgarians. Božica MLADENOvić, 1996, Žena u Topličkom ustanku 1917, p. 78.

53. Velimir PILETIĆ, 2002, Sudbina srpskog oficira, p. 66.

54. Ibid.

55. AS, (Arhiv Srbije) [Archives of Serbia], Đ-2, (Centralni komitet Saveza komunista Srbije) [Central Committee of the League of Communist of Serbia], OK Ar, 59.

56. A woman's head was shaved in July 1944 because her brother was in Partisan movement, while another woman was beaten and raped because her husband was in the Partisan movement. AS, G-25, f. 39, Zl. Br. 5361.

57. VA, С̌a, 80-2-45.

58. AJ, 110-40-107.

59. Kosta NIKOLIĆ, 1999, Istorija ravnogorskog pokreta 1941-1945, p. 310.

60. DAVIDović, TIMOTIJEVIĆ, 2004, Dan posle - uništavanje organizacije JVuO i uspostavljanje vlasti komunista u čačanskom kraju 1944-1945, p. 34.

61. AJ, 103-167-183.

62. Momčilo Mitrović, 2007, Srpska nacionalna čast pred zakonom 1945: godine, p. 326.

63. Two women, mistresses of German officers, were executed by a firing squad in Požarevac. Srđan cVETKović, 2006, Između srpa i čekića: Represija u Srbiji 1944-1953, p. 212.

64. Some men, as was the case in Niš, returned to Serbia with their German wives. AS, BIA, IV-12.

65. Among the women indicted by the Court of Honor, was a former gymnasium pupil, who was sentenced to a year of easier forced labor because she maintained friendly relations with the members of the occupation forces. She was guilty because she had been seen in a bathing suit at the beach in Čačak twice with a German officer and because she fraternized with the so called domestic traitors. DAVIDOVIĆ, TIMOTIJEVIĆ, 2004, Dan Posle..., p. 43.

66. A group of six women were convicted in Niš, who were mostly married, as was underscored. Nataša MILIĆEvić, 2009, Jugoslovenska vlast $i$ srpsko građanstvo 1944-1950, p. 337.

67. MITROVIĆ, 2007, Srpska nacionalna čast..., pp. 59-72.

68. Istorijski arhiv Užice, Okružni sud u Užicu [Historical Archives of Užice, District Court of Užice], KNO i konf. Ča/a 1945. 
69. AS, BIA, I-36.

\section{RÉSUMÉS}

Ce texte étudie les circonstances dans lesquelles des femmes ont eu des relations intimes avec les occupants allemands en Serbie pendant la Seconde Guerre mondiale. On y analyse la politique et l'attitude des mouvements de résistance envers ces femmes tout comme l'importance sociale de ces relations.

La fraternisation intime avec des membres des troupes d'occupation a été un phénomène typique dans tous les territoires occupés par les forces allemandes pendant la Seconde Guerre mondiale. Qu'elle ait été dépendante du type de l'occupation, du nombre des occupants ou de sympathie envers le nazisme, cela a été la forme de collaboration la plus détestée et condamnée, car elle était vue comme une trahison à la fois nationale et sociale à l'encontre des normes patriarcales et morales en vigueur.

Couper les cheveux devint ainsi une punition infligée par le mouvement Ravna Gora aux femmes qui avaient des relations avec les soldats allemands pendant l'Occupation. D'un autre côté, après la Libération, le Mouvement de libération nationale organisa des «marches » pour les femmes accusées de «collaboration horizontale ». Ces deux châtiments - cheveux tondus ou longues marches - outre des accusations pour relations sexuelles, contenaient souvent en arrière-plan une condamnation idéologique. Cacher l'idéologie sous une accusation sexuelle était une tentative pour dégrader les femmes et les priver de l'égalité des droits et de leur émancipation. Le traitement de la collaboration différencié selon les sexes était une tentative pour rétablir la domination masculine et le rôle traditionnel des sexes.

The paper will examine the circumstances in which women conducted intimate relations with the German occupiers in Serbia during WWII. It will analyze the policy and stand of the resistance movements towards such women as well as the social importance of these relations.

Intimate fraternization with members of occupying forces was typical phenomenon for all territories under German occupation during World War II. Although it depended on the regime of occupation, number of the occupying forces and general sympathies towards Nazism, it became the most detested form of collaboration. Women fraternization with Germans was condemned since it was considered betrayal of national and patriarchal norms and morals.

Cutting of women's hair became a method of punishing women for intimate relations with German soldiers by Ravna Gora Movement during the occupation. On the other hand, after liberation, National Liberation Movement organized trails for women charged for "horizontal collaboration". Punishment by cutting hair as well as post-war trails, beside real charges for sexual relationships had, in numerous cases, background in ideological disapproval. Concealing ideology behind sexual charges was an attempt of women gender degradation and deprivation of their right on equality and emancipation. The gender differentiated treatment of collaboration was an attempt to re-establish male dominance and traditional gender roles.

ЧЛАНАК СЕ БАВИ ОКОЛНОСТИМА ПОД КОЈИМА СУ ЖЕНЕ СТУПАЛЕ У ИНТИМНЕ ВЕЗЕ СА НЕМАЧКИМ ОКУПАТОРОМ У СРБИЈИ ТОКОМ ДРУГОГ СВЕТСКОГ РАТА. АНАЛИЗИРАНА ЈЕ ПОЛИТИКА И ОДНОС АНТИФАШИСТИЧКИХ ПОКРЕТА ПРЕМА ТАКВИМ ЖЕНАМА, КАО И ДРУШТВЕНИ ЗНАЧАЈ КОЈИ СУ ВЕЗЕ ИМАЛЕ. 
INDEX

Index géographique : Serbie

Mots-clés : femmes, femmes, collaboration horizontale, collaboration horizontale, Occupation, Occupation

Thèmes : Économie, Sciences sociales

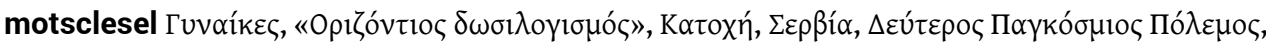

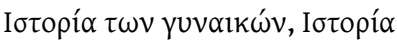

Keywords : Women, "Horizontal Collaboration", Occupation, Serbia, Second World War, Gender history, History

motsclestr Kadınlar, "Yatay İşbirliğ̆i”, İşgali, Sırbistan, İkinci Dünya Savaşı, Cinsiyet geçmişi,

Tarih

Index chronologique : vingt-et-unième siècle

\section{AUTEUR}

LJUBINKA ŠKODRIĆ

Archives of Serbia, Belgrade 